\title{
Pirates and the Environment: Bajo Tribe Study in Marine Conservation
}

\author{
Agustinus Supriyono ${ }^{1}$, Alamsyah $^{1 *}$, Mualimin $^{2}$ \\ ${ }^{1}$ Department History, Faculty of Humanities, Diponegoro University, Semarang - Indonesia \\ ${ }^{2}$ Department English, Faculty of Humanities, Diponegoro University, Semarang - Indonesia
}

\begin{abstract}
Pirate is considered as one of the oldest professions in the world. The existence of pirates in the archipelago was first recorded in the 5th century $\mathrm{AD}$. In the period of 15 th to the 16 th century, pirate activities increased due to political and economic changes in the archipelago. One of them was the arrival of European traders which made most people in the archipelago encouraged to do piracy, including those done by Bajo tribe. The tribe which is from Sulawesi was a respected pirate at that time who had a wide operations area in the archipelago. The piracy targets are Europeans and indigenous traders. Bajo tribe was not only good at piracy but also had a concern for marine and coastal conservation. The coastal areas Preservation can be seen from the efforts to preserve coral reefs, fish and mangrove.
\end{abstract}

Keywords. Bajo Tribe, Pirates, Preservation, Marine and Coastal

\section{Introduction}

Pirates are rogues or intruders in the sea or near the coast which is believed to have existed for thousands of years ago [1]. Pirates have been recorded in the archipelago since the 5th century AD. People in the archipelago in their tradition admit that pirates are sometimes seen as a crime, but in a condition, their existence is perceived as a heroic act. There are quite a lot of literary works in the archipelago that feature pirate figures as its main role [2]. Pirates in the archipelago grew rapidly when entering the 16th century.

The pirates development is influenced by several supporting factors. In the 16th century $\mathrm{AD}$, the archipelago trade routes began to bustle with the traders arrival from Europe, such as Portuguese, Spanish and Dutch. This European trader caused increasing demand for several types of commodities in the archipelago [3]. Ports in Sumatra, Java, Kalimantan, Sulawesi, Little Sundas and Maluku had become more crowded since 16th century. Shipping and trading activities in the archipelago provoke the pirates to do theft to merchant ships. Some triggers of the pirates emergence caused by arbitrariness, coercion, and extortion by Westerners. As the result, the oppressed kings, indigenous chiefs, traders, and sailors took

*Corresponding author: alam_mahir@yahoo.com 
the fight one of them through piracy They are motivated to make a living through theft or piracy at sea [4].

One of the respected pirates in the 16th century was pirate from Bajo tribe. This pirate had operation area covering very extensive waters area, it was almost the entire archipelago [5]. The Bajo tribe, beside doing piracy, also arresting the hijacked crew or people who lived on the coast to be sold as slaves [6]. On the other hand, this tribe had local wisdom in preserving the sea. They had a view that the sea has a vital value in life. Bajo tribe try to protect the sea sustainability by maintaining coral reefs and fish preservation in the sea. This behavior is the result of Bajo tribes traditions that is maintained [7]. The behavior of protecting and preserving the sea is quite unique, considering that Bajo tribe also work as pirates who are identical with destructive behavior.

\section{Method}

This study uses a historical method consisting of heuristics, criticism, interpretation, and historiography [8]. Heuristics is the process of finding primary and secondary sources [9]. Primary sources were obtained from observations, government or individual archives, and events photos. Secondary sources are taken from articles relevant to research taken from books, journals, and other literature. Secondary sources can be obtained from libraries, personal collections, and the internet. The available sources are then criticized and interpreted. The results of the above analysis are then linked and reconstructed into an article about "Pirates and the Environment: Bajo Tribe Study in Environmental Conservation"

\section{Results and Discussion}

\subsection{Pirates in the Archipelago}

Pirates are stated to be one of the oldest professions in the world because they have existed since in the ancient time [10]. According to evolutionist thought, the pirates appearance was a continuation of hunting, the earliest economic level. Maritime community considers that hunting is fishing which then develops in catching everything that is found in the wide sea. The sea area is considered a free business place, as is the forest area for land-dwelling people who wander in the forest to collect food. In the higher civilizations development saw the act of taking freely at sea declared as piracy or pirates. Another construction is economic evolution, which is the initial stage of trade [11]. The piracy problem at sea has emerged since hundreds of years ago [12].

In 413-414 AD, Fa Xian (a Buddhist monk from China) on his way came back home from India through Southeast Asia waters territory wrote in his notes that the Southeast Asian region was full of pirates [13]. Fa Xian passed through Nusantara region around the Malacca Strait. Based on his notes it can be concluded that pirate activity in the archipelago has existed since the 5th century. According to Gaynor, during Srivijaya Kingdom (around 7th to 12th century) there were many pirates around Srivijaya waters territory [14]. Pirates were more intensive in 15th and 16th centuries due to changes in political, trade and economic constellations. The presence of Europeans in Southeast Asia led to the acceleration of pirates existence and they were rulers in the ocean [15].

The archipelago sea trade lane has never been deserted from piracy acts [16]. So Tomi Pires (Portuguese explorer) described several pirate actions around the 16th century in the archipelago. A Javanese or Malay ship was able to rob or besiege ten Chinese ships that were doing trading activities. The action took place around the Indian Ocean. This was also happened in Aceh, where robberies often took place and were seen as pirate's lair. During 
Demak period, the action of pirating or robbing each other done by Sundanese (Hindu) traders against Javanese or Demak (Islamic) traders. Sundanese and Javanese traders, when met in the open ocean, often pirate or rob each other, depending on who was stronger when they met [17]. In Makassar, the pirate activity was led by Kraeng Galesong and Montemarango. This figure later joined the power of Gowa-Tallo Kingdom under Sultan Hasanuddin rule [18].

Pirates have interdependencies with sea people and sea kings [19]. This dependence occurs when the sea king needs sea people to develop his maritime power. Conversely, sea people also use the cooperation to obtain the protection from the king. When their economic pressure happened the cooperation between sea people and pirates emerged. On the other hand, the king who needed slaves and commodities seized by the pirates was ready to make a transaction [20]. The relationship between pirates, sea people and the king are not only a dependence relationship but it can be in the form of sharing roles, positions, and even conflict and dominance could be happened between the three sea community entities. These three entities make agreements and conventions of the rules (law) in regulating activities at sea $[21]$.

\subsection{Bajo Tribe as Legendary Pirates}

Bajo is a tribe that inhabits waters in east Makassar Strait, east coast of Kalimantan, Alor Island, Banggai Islands, Togian Islands in Tomini Bay, Bacan Islands, and Sulu Islands. This tribe is sea wanderer who was very tough. Some of them live in houseboats called leppa or lepa-lepa and some live in houses on the water or by the beach. Bajo tribe have a main livelihood as fisher or fishermen. They sail to the high sea every day, to a place where in their experience there are many fish. Bajo tribe depend their entire lives on the sea. They consider that the sea is not only a "village" where they were born and lived until the end of their lives, but also a place to bet their fate and hang all their hopes [22].

Bajo tribe is one of the tribes that linked to be involved in piracy in the archipelago in the 15 th and 16th centuries. The name Bajo for some groups often gets stereotypes as raider or pirates. According to an oral story that developed near the Bajo village, it was stated that they were a group of pirates who came from Sama people. Some people refer to Sama as Bajo people, which means a group of pirates Bajo people are well-known as a group that inhabits the sea and spreads throughout the archipelago, especially in Eastern Indonesia and is considered a robber tribe [23].

According to Portuguese reports, when the Portuguese ship which under Francisco Serrao leadership came to Maluku, they met pirates on Lucipino Island (Nusa Turtle), which located in the west of Banda Islands. The pirates are the Straits people or Bajo tribe [24]. According to Tome Pires, Bajo tribe raided up to Pegu in the west and to Maluku, Banda in the east. This tribe visited islands around Java and surrounded Sumatra island. Their base is on several small islands adjacent to the west coast along the South Sulawesi peninsula [25]. Lombard stated that Bajo tribe locations were at the robber bases location (pirates) [26]. The merchandise and looty were brought to Jumaia (on Seven Island), where they market the looted products [27]. This tribe, beside doing property piracy, also captured crew of the hijacked ship or people who lived near the coast to be sold as slaves [28]. They had done piracy on Kangean Island (Madura). In this place there is a concentration of Bajo settlements on Kangean Island which is believed to be closely related to piracy and shipping lanes [29].

Bajo tribes have piracy skills, then followed by Malay sailors, and Bugis who follow in Bajo tribe footsteps as pirates [30]. Bajo tribe follow Bugis tribe shipping route to Australian waters [31]. In Australia they also do piracy. They pioneer the shipping lines to various Archipelago as a network operating area of lanun pirate that come from Southern Philippines. They attack Kangean and Bawean Islands as well as other places [32]. Bajo tribe was just 
involved in pirate activities around the 15th to 16th century. In the following period, there were no sources about Bajo tribe involvement in doing piracy.

\subsection{Pirates in Marine and Coastal Conservation}

Bajo tribe is known as a tribe that is closely related to pirate activity, because it is related to their wandering behavior. This tribe has a living culture that tries to be friendly with their natural surroundings, that is sea. Bajo tribe culture is a legacy from their ancestors who have lived side by side with the sea for hundreds years. Bajo tribe has a philosophy about the sea sanctity that said, Papu manak ita lino bake isi-isina, kitanaja manusia mamikira bhatingga kolekna mangelolana (God has given this world with everything on it, humans think about how to obtain and use it). Bajo people preserve marine resources, among others, by participating in planting mangroves in coastal areas, as happened in East Sinjai, South Sulawesi. Their knowledge about planting mangrove is a local wisdom that has been carried out since their predecessors era. Bajo tribe also has a concern for coral reefs preservation as underwater ecosystems buffer. In fishing they choose using large nets, so that only large fish are caught [33].

The local wisdom owned is reflected in their fishing activity or obtaining other marine biological resources that have been determined by the time, equipment used, and the area where the fishing activity is located. For example, in January to March, Bajo fishermen usually dive to take tripang; in July and August they take clams and types of shellfish; in September to December some of them will fish and some catch fish with nets. April is a rest period because at that time it was a transition period so large waves often occur [34].

Bajo tribe has a tradition of mamia kadialo (go out to sea), in which there are restrictions that should not be done by families who are left behind or those who are at sea. This tradition has restrictions, among others, not allowed to throw into sea waters such as sea cucumber washing water, wood charcoal or kitchen ash, cigarette butts and ash, chili water, ginger, and orange juice. This tradition prohibits Bajo people from washing cooking utensils (pans) in sea waters. The used washing water and those ingredients should be collected and then dumped on land. They forbid eating turtle meat, if not be obeyed, it is believed that it will bring disaster, storm, evil spirit disturbance, even those who go to sea will not get anything. Turtles for Bajo Tribe are believed helping a lot of people who get a disaster so that they are not allowed to be killed. The prohibition in Mami Kadialo is an effort to use marine resources within a certain period. The prohibition for the residents to kill sea turtles and approach certain of coral reefs barrier has a value of animal preservation to support the existence of marine and coastal ecosystems [35].

The tradition of Parika System is an institutional system that exists in the fishermen community of Bajo Tribe. This tradition has a conservation value, limits fishing, gives room for fish to lay eggs and give birth. In the Parika system if there is a person who does not obey, he/she will be reprimanded. As for Karang Tapotong (Karang Pakitta) tradition, that is the tradition of respecting the sea in fisheries management by conducting a ritual of asking for permissions to the sea before starting activities [36]. They have the determination to hold their ancestral customary values and traditions especially related to fishing [37]. Thus, this tribe upholds their ancestral values as an effort to preserve the sea, the place where they hang their lives.

\section{Closing}

Pirate activity in the archipelago has existed since 5th century based on Fa Xien's note. In the 15 th Century to the 16 th, the pirates existence had changed due to political, trade and economic constellations. Europeans arrival in 16th century made the indigenous groups 
pressed so they did the piracy. During this period pirates were almost evenly found throughout the archipelago sea area. The piracy was not only carried out to foreign traders, but also to traders from the archipelago. One of the pirate mob is Bajo tribe, a respected pirate. Bajo pirates have operational areas from Sumatra, Maluku, and even more. They not only rob property, but also capture people for sale as slaves. Their bases are around the sea of South Sulawesi and in Penang (Malacca). This tribe also has a strong local wisdom to preserve the sea. They are very concerned about coral reefs preservation and only catch big fish. Their attention to the environment is reflected in their efforts to preserve mangrove. For them, the sea and the coast have a vital value for Bajo tribe survival so it must be maintained and preserved.

\section{Acknowledgement}

The research is funded by Directorate of Research and Community Service (DRPM) Higher Education (DIKTI) Repbulic of Indonesia in 2020 budget year.

\section{References}

1. Nasional, Departemen Pendidikan., Kamus Besar Bahasa Indonesia, (2008)

2. Lapian, A. B., Orang Laut Bajak Laut-Raja Laut: Sejarah Kawasan Laut Sulawesi Abad XIX, (2009)

3. Syafiera, Aisyah., "Perdagangan Di Nusantara Abad Ke-16", AVATARA, Volume 4, No. 3, Oktober (2016)

4. Tarling., The Cambridge History of Southeast Asia, (1992)

5. Pires, Tomé., Suma Oriental: Perjalanan dari Laut Merah ke Cina \& Buku Francisco Rodrigues (terj. Andrian Angkasa dan Anggita Pramesti). (2014)

6. Lapian, A. B., Orang Laut Bajak Laut-Raja Laut: Sejarah Kawasan Laut Sulawesi Abad XIX, (2009)

7. Susilowati, Endang., Etnis Maritim dan Permasalahannya, (2012)

8. Garraghan, Gilbert., A Guide to Historical Method (1947)

9. Herlina, Nina., Metode Sejarah (2008)

10. Arielli, T. I., Modern Maritime Piracy After The End of The Cold War-A Challenge for The Marine and Coastal Management, (2012)

11. Lapian, A. B., Orang Laut Bajak Laut-Raja Laut: Sejarah Kawasan Laut Sulawesi Abad XIX, (2009)

12. Collins, V. E., "Dangerous Seas: Moral Panic and The Somali Pirate", Journal of Criminology, Vol. 45, No. 1, (2012)

13. Lapian, A. B., Orang Laut Bajak Laut-Raja Laut: Sejarah Kawasan Laut Sulawesi Abad XIX, (2009)

14. Gaynor, J.L., "Piracy in the Offing: The Laws of Lands and the Limits of Soverignty at Sea", Antropological Quaterly, 85(3), (2012)

15. Majul, C. Adib., Muslim in the Philipines, (1973)

16. Iskandar, Mohammad., "Kurun Niaga dan Keruntuhan Tradisi Maritim di Jawa 15001680", Abad Jurnal Sejarah, Vol. 1,No. 2, Desember (2017)

17. Pires, Tomé., Suma Oriental: Perjalanan dari Laut Merah ke Cina \& Buku Francisco Rodrigues (terj. Andrian Angkasa dan Anggita Pramesti). (2014)

18. Iskandar, Mohammad., "Kurun Niaga dan Keruntuhan Tradisi Maritim di Jawa 15001680", Abad Jurnal Sejarah, Vol. 1,No. 2, Desember (2017)

19. Lapian, A. B., Orang Laut Bajak Laut-Raja laut: Sejarah Kawasan Laut Sulawesi Abad $X I X,(2009)$ 
20. Pradjoko, Didik., "Upaya Memberantas Bajak Laut Modern di Perairan Selat Malaka dan Kepulauan Riau”, Abad Jurnal Sejarah, Vol. 1,No. 2, Desember (2017)

21. Rochmiatun, Endang., "Orang Laut, Bajak Laut, dan Raja Laut: Dinamika Kehidupan dan Kekuasaan dalam Naskah Kontak Sultan-Sultan Palembang Abad 18-19”, Jurnal Manassa, Vol. 6, No. 1, (2016)

22. Susilowati, Endang., Etnis Maritim dan Permasalahannya, (2012)

23. Tahara, Tasrifin., "Kebangkitan Identitas Orang Bajo di Kepulauan Wakatobi", ANTROPOLOGI INDONESIA Vol. 34 No. 1 (2013)

24. Jacobs, Herbert (ed)., A Treatise on the Moluccas, (1971)

25. Pires, Tomé., Suma Oriental: Perjalanan dari Laut Merah ke Cina \& Buku Francisco Rodrigues (terj. Andrian Angkasa dan Anggita Pramesti). (2014)

26. Lombard, Denys L., Nusa Jawa Silang Budaya. Jilid 2. Terj. (1996)

27. Cartesao, Armando., The Sumo Oriental of Tome Pires. An Account of the East. 2 Jilid. $X X X I X$ dan XL terj. Armando Cartesao. (1944)

28. Lapian, A. B., Orang Laut Bajak Laut-Raja Laut: Sejarah Kawasan Laut Sulawesi Abad XIX, (2009)

29. Bustami, Abd. Latif., "Folklor Kangean: Suatu Kajian Cerita Bajak Laut (Lanun) Sebagai Sumber Sejarah Kawasan”, BAHASA DAN SENI, Tahun 32, No. 2, Agustus 2004

30. Pelras, Christian., The Bugis, (1996)

31. Lapian, A.B., Nusantara: Silang Bahari dalam Chambert-Loir Henri dan Hasan Muarif Ambari (eds), "Panggung Sejarah Persembahan kepada Prof. Dr. Denys Lombard", (1999)

32. Bustami, Abd. Latif., "Folklor Kangean: Suatu Kajian Cerita Bajak Laut (Lanun) Sebagai Sumber Sejarah Kawasan”, BAHASA DAN SENI, Tahun 32, No. 2, Agustus 2004

33. Susilowati, Endang., Etnis Maritim dan Permasalahannya, (2012)

34. Susilowati, Endang., Etnis Maritim dan Permasalahannya, (2012)

35. Utina, Ramli., Kecerdasan Ekologis Dalam Kearifan Lokal Masyarakat Bajo, (2012)

36. Hasrawaty, Esti; Pigoselpi Anas, dan Sugeng Hari Wisudo., "Peran Kearifan Lokal Suku Bajo dalam Mendukung Pengelolaan Kawasan Konservasi di Kabupaten Wakatobi”, Jurnal Penyuluhan Perikanan dan Kelautan, Vol. 11 No. 1 April (2017)

37. Saad, Sudirman., Bajo Berumah di Laut Nusantara, (2009) 